\title{
Intercultural and Life-long-Learning Based on Drama-in-Education* Prepositions for Multidimensional Research Projects
}

\author{
Alkistis Kondoyianni \\ University of \\ Peloponnese
}

\author{
Antonis Lenakakis \\ Aristotle University \\ of Thessaloniki
}

\author{
Nikos Tsiotsos \\ Primary \\ Education School
}

\begin{abstract}
Our principal aim in this paper is to put forward ways for an in-depth investigation of the role of drama in education. These concern drama both as a methodology in itself in the field of education and Lifelong-learning, and as a means capable for implementation in other areas of the curriculum. Our preoccupation with alternative dramatic forms, such as Puppet Theatre, dramatised narrations and creative writing-in-role, was due to our ambition to involve a rather large spectrum of prospective participants (students, prison convicts, elderly people and immigrants). It has also been our aim to involve people who seek ways to improve their professional competence (people working in museums, public libraries, or tourism, and generally people for whom drama could be useful in their work places). In fact, our main objective has been the consolidation of Drama in Education in a context that, in our conviction, rightly deserves in the field of scientific and social work.
\end{abstract}

Keywords:Drama in Education, creative drama, lifelong learning

$$
\ddot{O}_{z e t}
$$

Bu araştırmanın amacı, bir eğitim yöntemi olarak ĕgitimde yaratıcı dramının rolünü yetişkin ĕ̆itimi ve yaşam boyu öğrenme bă̆lamında ulusal ve uluslararası projelere dayalı olarak derinlemesine incelemektir. Eğitimde yaratıcı dramanın burada hem bir yöntem hem de disiplin olarak eğitim ve yaşam boyu ögrenme ortamlarında kullanımı ele alınmıştır. Temel amaç; kukla tiyatrosu, dramatik öyküler, rol içinde dramatik yazma alternatif drama çalışmalart yoluyla drama çalışmalarına katılacak hedef grupların dağılımını olabildiğince genişletmektir. Bu nedenle çalışma eğitimde yaratıcı dramanın bir sosyal çalışma ve araştırma alanı olarak hak ettiğ $i$ yeri gösterebilmektir. Çalışma ĕ̆itimde ve yaşam boyu öğrenme bă̆lamında yaratıcı dramayı ele almaktadır. Bu nedenle farklı sosyal konulara vurgu yapılmış ve bu çalışmaların etkili olarak yapılabilmesi için yaratıcı dramanın nasıl işe koşulacağı tartışılmıştır.

Anahtar Sözcükler: Eğitimde drama, yaratıcı drama, yaşam boyu ögrrenme

\section{Introduction}

Our study focuses on Educational Drama and Lifelong Learning. In such a manner, it pays particular emphasis on a variety of social issues that, in our view, could be effectively handled, and investigated, through the practice of drama. Nevertheless, and since we have not yet well established research results from the proposed fields, we ought to recognise the range of complexities we have to cope with. The latter, notwithstanding the difficulties they might entail, present a real challenge to us. Drama- in-Education has, been fruitfully exercised at all levels of education and lifelong learning up to now. Its capacity to sustain suspension of

\footnotetext{
${ }^{*}$ In this article the term Drama-in-Education will appear at times as Theatre-Pedagogy, due to the use of German references where this term is used as such.
} 
disbelief ${ }^{1}$, to promote intelligent feeling ${ }^{2}$, and generally to contribute to the aesthetic education of children and young people ${ }^{3}$. Besides, it has been proven capable to foster actual learning at all levels of the curriculum ${ }^{4}$, has rendered it popular among both educationalists and students.

The latter, through an active participation in imagined worlds, involving an enhanced variety of knowledge and vocational aspects, can actually rehearse their prospective responses to situations that await them in actual life. Apart from the above, drama turns up in the curricula of University Departments, not only those dealing with Education, but also those concerned with diverse disciplines such as Sociology, Medicine, Foreign Languages or Technology ${ }^{5}$.

Recent insights in the field of human sciences, along with social, economic, and political conditions -as they are formed in Europe and worldwide- require novel and audacious educational policies. New approaches to educational praxis are constantly being sought along with new methodologies for educational research. In addition, novel material and techniques capable of furnishing pleasant, encouraging and secure educational environments are also being intermittently experimented.

All these call for an education that respects principles of democracy, whilst recognizing and respecting individual and cultural divergences. Such an education could not, but enable a free and protected interaction among students of various social groups, whilst allowing the utilization of modern educational technologies. Besides, such an education takes account of the respect towards natural environment, whilst fostering the peaceful and harmonic co-existence of individuals as students and as prospective citizens. In such an educational context we take the license to consider the arts -and most importantly, drama as a dynamic variable, very germane to our rich European cultural inheritance.

\section{Drama -in-Education/Theatre Pedagogy}

Our study concerns the planning and a cooperation of different scientific, cultural and social groups on the one hand, and the combination of different forms of artistic expression and creative activity, on the other. In such a venture we pay particular emphasis on drama and the arts,

\footnotetext{
1 'Suspension of Disbelief": a term coined by Samuel Taylor Coleridge (1907, in his Biographia Literaria) to stress the semblance of truth that a writer infuses into a work of literature, so that the reader would suspend judgment concerning the implausibility of the narrative, while accepting the fictional characters and actions as temporarily "real". The term has been widely used by the pioneers of educational drama, and most notably by Heathcote and her devotees, to stress the importance of drama's fictional reality created in the classroom capable to brig about action and interaction among students-characters who also experience the created condition, they are asked to act in, as temporarily 'real'. In the words of O' Toole (1992), "Drama-in-Education and Theatre-in-Education are two more such genres. They take place in settings which actively mediate against the ready suspension of disbelief; schools have very specialised purposes, and very strong messages of reinforcement for them-many of the practices of schooling are specifically designed as focussing devices for those purposes" (p. 50).

2 This should not be confused with the term "Emotional Intelligence' as has been put forward by Goleman (2004). It is not concerned with a subject's social skills or capacity to emotionally adapt to ever-changing life conditions. Rather, it is concerned with the "feeling ideas" and subject-reflective action (present in all works of art) that renders possible the communication of ideas through works of art (see: Langer 1977, Witkin 1974, Ross 1978, 1984, Hentschel 2010).

3 See: Hentschel 2010.

4 "A problem with many curriculum guides" says Taylor (2000), "is that they present objectives and content in a static and lifeless manner seemingly ignoring the fact that people have to curriculum happen. Any good drama teacher knows that curriculum is a lived experience; it is negotiated with colleagues and students - a fallible event dependent upon the abilities, moods and backgrounds of those who construct it" (p. 7, our emphasis). Also, regarding the role of the drama-teacher in the formation of a "living curriculum", see: Lenakakis 2004, whereas concerning drama's capacity to act as a factor that promotes a multi-dimensional learning, see: Domkowsky 2011.

5 See: Fines and Verner (1974), Adiguzel (2008), Dörger \& Nickel 2005.
} 
since, in their course through time these universal symbolic activities have developed common forms and patterns capable to summarise human creativity and inventiveness, in response to individual and social needs ${ }^{6}$. Especially with regard to theatre, interaction between various countries, ethnic groups and cultures appears particularly evident, both diachronically and synchronically: from the rituals of prehistoric African societies to the modern rites associated with the launching of Olympic Games; from ancient Greek drama to Kabuki dance theatre; from Boal's Theatre of the Oppressed to Forum Theatre in Australia; from Brecht's theatre in Germany to the theatre in Pakistan or New York ${ }^{7}$. This is because theatre allows vivid common understandings among people, regardless of their physical and cultural diversities. Indeed, drama and theatre can condense inside their expressive medium social dramas and universal binary opposites -as they have been put forward by Levi-Strauss (1963)-, such as: realities and dreams; happiness and despair; passions and sufferings. They are also concerned with loneliness and community in the immense stage of the world; a world composed and symbolically embellished with partial sceneries, props, rooms, houses, hotels, streets, airports, factories, jobsites, offices, cities, villages, local communities and deserts. And this universal scenery exists regardless of borders, languages, religions, skin colour and financial recourses.

On that account, Drama and Theatre become nodal points of universal meetings capable of uniting all participants, rendering them members of a global community. This transformation is rendered possible, due to theatre's capacity to transform everyday realities into everyday dramas (Pinkert, 2005, O’ Toole \& Daneman, 1996). These dramas imbue peoples' lives with a sense of metaphor, thus rendering them full-pledged and more meaningful (Boal, 1993, 1996, Pammenter \& Mavrokordatos, 2003, O’ Toole \& Daneman, 1996, Somers 2006).

Drama and Theatre make up one of the dominant means of communication of ideas and behavioural manners in our civilization. They assist people in their attempts to rehearse basic role models which aid them in the formation of their own personal identities, ideals and social values ${ }^{8}$. All these, in turn, serve as prototypes for the shaping of their social living, which also puts into formation models of political frames of mind. The latter do not take shape in a random and unreflective manner; rather, they are subjected to a sedulous examination in Drama's social laboratory; a laboratory that provides them with a more precise and tangible context ${ }^{9}$. Many a time theatre has presented human behaviour through a magnifying glass that capacitates spectators the better to envisage and apprehend it. And it is, in fact, this realization that renders individuals capable of criticism and revolt, whilst imbuing them with the will to either alter their unbearable realities or abolish them from their personal or social landscapes.

Drama and the arts in general, form an effective way for sensing and comprehending the world. They function not only through seeking natural and social laws to human action; rather , they create images capable of allowing a holistic access to natural and social phenomena. ${ }^{10}$

\footnotetext{
6 Moore for the function of symbolic forms, see: Cassirer 2010, Langer 1977, Fuchs 1999, 2011.

7 See: Fischer-Lichte 1999, 2008, Grammatas 2012, Koch 1998, 2012, Kondoyianni 2008, Lehmann 2006

8 For an attempt to denote the role of drama as a critical pedagogy agent, see Doyle (1993).

9 "My own view is that, limited as this learning experience may be in terms of an art form, it would be perverse for a drama teacher to exclude it on these grounds. It does, after all, give practice in the skill that is basic to all kinds of acting, which is: an ability to engage with something outside oneself using an 'as if' mental set to activate, sustain or intensify that engagement" (Bolton 1982, p. 137).

10 For an account of the holistic vision of the arts and its role in child's thinking, see Reid (1986) and Abbs (1979, 2003). See also the Schillers's (2004) famous maxim about the whole-dimentional activation of man in play:"man only plays when in the full meaning of the word he is a man, and he is only completely a man when he plays (Letter XV).
} 
They enrich human minds in a manner that aids them to transcend and expand their conceptions of life. Through theatrical processes people become able to understand the world as a much broader and richer entity than the narrow social milieu where each individual lives. These processes give rise to experiences that bear, for the spectators, transitional phenomena, dynamic areas of experience, through which internal and external realities are joined in a more controllable manner ${ }^{11}$. According to Winnicott $(1992,2005)$, transitional phenomena imbue human existence with valuable insights and offer meaningful outlets to people's agonies. In fact, central in a Drama-in-Education workshop is the child as a subject and object of action since he/she experiences him/herself as a role player. $\mathrm{He} /$ she and the enacted dramatic character presumes an interaction, a symbiosis of the ego and the other protected by the otherness.

A more analytical eye on the procedures taking place in a drama workshop ${ }^{12}$, reveals the central importance of child or the adult as a role-players and as both subjects and objects of their actions The formation of a subjective imaginative reality presupposes an interrelation of the role-player with the character (as an archetypical figure), as well as with the fictional context into which this character acts.

In the same context, the regularity of the real life is transformed into the play's own peculiar regularity. These two realities relate with each other in a dynamic, critical and, at times, subversive relationship, where the life history and the whole personal repertoire of the actorperson participates in a holistic, yet ineffable manner.

Nevertheless, while the personal play involves the construction of another reality that obeys to the personal conventions of the actor, the materials for the construction of such reality continue to be symbolic interpretations of the actors' real experiences. In such a manner, the symbolic activities in the play ${ }^{13}$ context can offer a fruitful context for the exploration of the external reality, ${ }^{14}$ as it is conceived and interpreted by each actor and each acting group. The free, safe, and, hence, creative action of the actor in the personal play, eloquently reveals attitudes, values, as well as internal conflicts of him/her. In such a context which is a selective fragment of the external reality (and, it has to be noted here, it is never the reality itself) the development of a fruitful inter-cultural conversation among participants and groups of participants is utterly facilitated. And this is because the joint action, the compliance to the play's rules for a common achievement, as well as the reflection over the collective fictional experience, incapacitates the participants to get more easily into one's other's shoes, and to consequently see reality with a different eye, and release individuals from their prejudices and fears towards the unfamiliar (Lenakakis, 2012).

\footnotetext{
11 For an interesting account of drama as a transitional experience see Schechner (1988) and also Turner (1974, 1978). In fact the former writer undertakes a combination between Winnicott's account on the transitional Phenomena with Victor Turner's view of the transitional nature of the social rituals, in an attempt to establish performance as an indispensible factor of social existence. To reiterate one of Bruner's (1996) views, culture shapes our cognition and provides us with the basic tools' with which we not only construct our reality but we also realise the best ourselves and also our potentials. Knowing our cultural milieu enable us to expand our understanding of the worlds whilst contributes to the development of memory, imagination and language (Olson \& Torrance 1999). Our cultural heritage and more specifically mythology and theatre, ancient Greek philosophy and literature, painting sculpture, music and popular culture and tradition have inside them dynamic cognitive forms which form unique achievements of the human spirit. From these dimensions and in relation with Luria's (1978) psycho-social theory, as well as with Vygotsky's $(1978,2012)$ sociocultural conception of human cognition, we are able to stress the importance of the involvement of the arts and drama in the context of education, as it comes about in accordance with the recent developments of psychology, education and technology.

12 See also: Lenakakis 2004.

13 A thorough account on the personal play of the child can be read in Slade's (1953) pioneering, and now classical, work.

14 For an interesting account on the dynamic and revolutionary character of art's otherness see Marcuse (1978).
} 
Art forms an alternative, dynamic and impelling way of learning, since it promotes aesthetic knowing (Langer, 1977) which, in turn, assists intuitive understanding, hence forming the grounds for our understanding and evaluation of our place in the world (Bruner, 1979, 1990, Reid 1986). Winnicot (2005) considers art as a "transitional" phenomenon, as a dynamic territory of experience, as an "Ego" and 'Non Ego' experience where man integrate internal and external entities (Winnicott, 2005). Apart from that, aesthetic illusion (Cattanach, 1996, Gombrich, 1960) offered by works of art constitutes a distant "otherness" which enables an exploration of the world, free from the constrains of tangible realities (Langer, 1977). Taking account of the, rather telling, assumption that that these "realities' constitute formal projections of oneself through a variety of expressive media, one could conclude that education through the arts is not only concerned with the understanding of the world, but also with that of the abilities of the individual him/herself (Witkin, 1974).

"I understand Theatre Pedagogy as a discipline of aesthetical education. From this point of view, theatre pedagogy is not understood as a collection of pedagogical means or tools that should introduce certain target groups to some desirable behavior or notable matter. In fact, the genuine issue of theatre pedagogy is theatre, its specific materiality and production. Aesthetical education therefore asks which experiences Theatre Pedagogy can procure for non-professional actors. And, subsequently, which educational effects may be opened through these experiences. Instead of starting with the question of what can be transmitted by the means of theatre (which aims and contents) - and therefore use theatre as a pedagogical instrument - I ask how theatre is produced and what kind of experiences can be won in this process. Pedagogical and social aims are not fully discarded. Yet, in terms of aesthetical education, I argue that they are not to be fixed in advance and in a normative way. Aesthetical experience that contains an educating experience is more likely to result from collective theatre work on a concrete subject" (Hentschel, 2008. See also Hentschel, 2010).

Best (2012) underlines the unbreakable link between the cognitive and the aesthetic while Ross (1984), through recognition of three important regions of every school curriculum, namely the academic, the practical and the cultural, emphasises the creative arts as a significant part of the latter, since in his own words: "The arts are important to a child's education because they are a way of knowing in their own right and offer unique access to certain dimensions of human experience" (Ross, 1984, p. ii, our emphasis).

Theatre, indeed one of the most significant forms of art, has become a dynamic means of expression. Its "significant form" (see Bell, 1914) had become a social and cultural educational agent with the three major tragic poets of the Greek Antiquity. Ancient Greek spirit, condensed in a dramatic speech, became a basic inspiration and an agent for the development of the modern European -and international- culture and spirit.

\section{Programmatic Texts of European and International Organisations}

The suggested research proposals demanded from us an initial concentration on the propositional texts of the EEC and various international organizations. The major aim of our exploration was to record the philosophy, the priorities and the basic principles involved in the texts at hand. These were concerned with three basic areas:

The place and the contribution of the arts in an intra-national co-operation regarding issues concerned with education and information, the promotion of information, creativity and educational research in the service of a more qualitative education, life-long learning and adult 
education.

More specifically these texts were as follows:

- the context, the whole philosophy and the aims of the strategy "Europe 2020" 15,

- the European Foundation for Quality Management, Excellence Model (2010) ${ }^{16}$,

- the conclusions of the European Council EUCO for the Education and Training ${ }^{17}$,

- the strategic context for the inter-European co-operation in the context of education and training (EK 2020) ${ }^{18}$,

- the results of the Council with regard to the working programme in the cultural field 2011-2014 ${ }^{19}$, the contribution of culture with regard to the implementation of the strategy "Europe $2020 " 20$, in the local and regional development ${ }^{21}$, in combating poverty and social exclusion ${ }^{22}$ as well as on issues of creativity and novelty spirit,

- the recommendation of the European Parliament and of the Council on the establishment of a European Quality Assurance Reference Framework for Vocational Education and Training, ${ }^{23}$

- the Road Map for Arts Education (UNESCO 2006) ${ }^{24}$,

- the Seoul Agenda: Goals for the Development of Arts Education (UNESCO 2010) ${ }^{25}$.

In addition to the above stated, we explored texts and research outcomes concerned with the basic viewpoints of lifelong learning, and, of course, the research findings from the field of Arts and Drama/Theatre in Education internationally . ${ }^{26}$

\section{Proposed Research Targets}

Through the proposed research programme and the corresponding activities that accompany it, we have set a series of aims that concern individuals on the one hand and drama groups on the other. The latter were considered in a national, European and international level. The same aims could also be considered as effective potentials acquired by participants in Drama-in-Education programmes:

$>$ For the members of the groups - for the target group (at a personal as well as at a group level)

- The development of a lifelong learning in both qualitative and quantitative terms, and the establishment of an educational culture where learning is viewed not as a mandatory activity, but as a process promoting personal integration and social cohesion. In line with all

15 http://ec.europa.eu/resource-efficient-europe/index_en.htm.

16 http://www.efqm.org/en/tabid/132/default.aspx.

17 http://www.consilium.europa.eu/uedocs/cms_data/docs/pressdata/en/ec/120296.pdf.

18 http://europa.eu/legislation_summaries/education_training_youth/general_framework/ef0016_en.htm.

19 http://www.consilium.europa.eu/uedocs/cms_data/docs/pressdata/en/educ/122111.pdf.

20 http://eur-lex.europa.eu/LexUriServ/LexUriServ.do?uri=OJ:C:2011:175:0001:0004:EN:PDF.

21 http://eur-lex.europa.eu/LexUriServ/LexUriServ.do?uri=OJ:C:2010:135:0015:0018:EN:PDF.

22 http://www.consilium.europa.eu/uedocs/cms_data/docs/pressdata/en/educ/117797.pdf.

23 http://eur-lex.europa.eu/LexUriServ/LexUriServ.do?uri=OJ:C:2009:155:0001:0010:EN:PDF.

$24 \mathrm{http} / /$ www.unesco.org/new/en/culture/themes/creativity/arts-education.

25 http://www.unesco.org/new/en/culture/themes/creativity/arts-education.

26 http://www.cedefop.europa.eu/EN/bibliographies/lifelong-learning-bibliography.aspx. See also Bibliography. 
these, we propose the exploration of language not only as a factor for communication, but also as agent for the expression of feelings and formation of peoples' personal identities.

- The promotion artistic expression and the bolstering of creativity as an agent of personal and collective empowerment. This aims at a more critical understanding of the world, and at an analysis of authoritarian structures. In such a manner, it enables people's collective actions for social transformation.

- The promotion of a research procedure that will aid the understanding of the multiple social constructions of meaning and knowledge, aiming at the formation of new meanings and knowledge.

- The reinforcement of communicability and the formation of an interactive environment of mutual communication and understanding.

- The empowerment of interpersonal relationships and the development of new means of communication.

- The multi-dimensional development of the members of the groups, aiding them to gain collective benefits in the context of local and wider areas, that is at a macro and at a microeconomic level.

- The promotion of communicational and interpersonal skills such as verbal/non verbal communication, active listening, expressing feelings, giving and receiving feedback.

- The enhancement of negotiation/refusal skills, such as negotiation and conflict management, assertiveness and refusal skills.

- The enhancement of empathy: that is the ability to listen and understand another's needs and circumstances and to openly express that understanding.

- The promotion of cooperation and team-work. More specifically, the development of an ability to respect others peoples' contributions and different styles of living, together with an assessment of one's own abilities and contributions to the group.

- The development of advocacy skills, such as influence and persuasion, networking and motivation.

- The development of abilities concerning decision-making and problem-solving, such as information gathering, evaluation of possible consequences of present actions of oneself and others, giving, in such a manner, alternative solutions to emerging problems.

- The enhancement of critical thinking, which is invaluable for the analytical exploration of values, social norms, beliefs, stereotypes whilst identifying relevant information and the sources for its collection.

- The elaboration of coping and self-management skills for increasing internal locus of control (self esteem, confidence-building skills, self awareness skills including awareness of rights, values, attitudes, strengths and weaknesses, goal setting skills, self evaluation -self assessment skills).

- The management of anger and of feelings related to grief and anxiety. The development of coping skills for dealing with loss, abuse and trauma. 
- The facilitation of self-expression, the awareness of one's rights, the appreciation of peace, the development of democratic attitudes and the respect to the principles of inter- and multi-culturalism.

- The development of emotional involvement, which forms a crucial factor in learning.

- The cultivation of feeling and the development of 'feeling ideas', as Witkin $(1974,1989)$ has put forward. Attention should also be paid on the growth of group expressiveness, the improvement of learning and the development of a familiar and safe ambience/environment.

- The development of imagination and inventiveness through the creative combination of adverse elements, the development of lateral thinking, the creation of new forms action taking in the world.

- The development of the whole personality and the growth of the potential abilities of each member of the group. This, in combination with the enhancement of a fruitful interrelation with the other members of the group, would, hopefully, lead to the development of socially active citizens.

- The growing of a personal empowerment through the strengthening of the ability of each member to establish his or her self in the group and into the wider community. This would lead to the enhancement or self-confidence of the group members, and would aid the development of a more critical view about the world.

$>$ For the local and European society (at a local, national and European level)

- The development of the creative abilities of the members of the local community through a line of action that moves from small-scale activities to a larger-scale ones.

- The creation of cultural sub-stratums at a local level. where lifelong learning acquires an aim inside the core centre of democracy. The promotion of polyphony and cultural diversity. This contributes to the improvement of the quality of life, mutual acceptance, communication, collaboration, and prevents behaviours adverse to human dignity.

- The promotion of attempts for the formation of cultural agents in the local community. They, in turn, contribute to the creation of new job opportunities.

- The strengthening of both vertical and horizontal collaborations between the cultural and other social sectors, co-operation between public and private sectors and the community of citizens.

- The encouragement of a project dedicated to what we came to call "cultural tourism". This will, hopefully, form a essential element for the establishment of steadfast tourism. Besides, rendering of due attention to environmental protection, the protection of cultural heritage, as well as the preservation of the natural landscape contributes a lot towards general quality of life. The resurgence of the intrinsic recourses of the local area with particular emphasis on material and immaterial heritage, cultural appearances and relevant acuities.

- The promotion of cultural activities, which take account of the particularities of each area.

- With regard to environmental education, the programme aims at the enhancement of 
the recognition of the inescapable necessity of the natural and cultural heritage (Ancient Theatres, ancient monuments). It is our hope that this will have positive results as regards the sensitization of those working in the tourist business, as well as the tourists themselves, towards our cultural heritage.

- The creative and fertile cooperation among Universities and the local bodies (city councils, local cultural associations, social institutions etc.).

- The dissemination of the research implications in Europe as well as the promotion of the collaboration between national Universities and European Universities and other educational and cultural bodies, so as to encourage exchange among them.

- The development of cultural activities which will focus upon the local particularities and seek the participation of citizens as well as their encouragement to take political and cultural actions.

- The promotion of mobility among researchers and creators/artists as well as the encouragement of European citizens towards understanding each other's civilizations through the exchange of experiences and skills, both during the phase of the planning as well as during the phase of the dissemination of the programme abroad.

\section{Suggested Research Actions}

\subsection{Research Objectives}

The methodological action we propose for the suggested pieces of research is concerned with the role/effectiveness of educational drama in a range of social and cultural regions. These might involve schools, museums, geriatric institutions, prisons, local authority cultural units, mental health institutions, playgrounds, social gatherings or galleries. The multiplicity of the interventions also require an assortment of drama-in-education strategies such as psychokinetic games, role-games, simulation games, physical theatre, free and structured improvisations, fairy tale narrations, puppet theatre and shadow theatre. These dramatic forms could lump together with other forms of aesthetic understanding and expression, such as plastic arts, music and dance.

\subsection{Suggested Methodological Approaches}

Our research recommendations could be grouped into two basic categories: (1) Basic Research and (2) Experimental Development ${ }^{27}$.

Firstly a theoretical work could be undertaken in order to produce new insights with regard to basic causes of various phenomena and events.

In a second face, the acquisition, formation and combination of existing knowledge and skills, for novel, modified work is sought. The recommended pieces of research could be carried out into three separated, yet interrelated, methodological units.

In a primary phase the structure and of the research intervention is set under discussion.

27 See: Community Framework for state aid for research and development and innovation, EU 2006 C 323/01 (in: http://eur-lex.europa.eu/ LexUriServ/LexUriServ.do?uri=OJ:C:2006:323:0001:0026:EN:PDF) and General block exemption Regulation 800/2008/EC, EU 2008 L 214/3 (in: http://eur-lex.europa.eu/LexUriServ/LexUriServ.do?uri=OJ:L:2008:214:0003:0047:EN:PDF). 
Here, decisions are taken with regard to the general framework where the research intervention will take place. In the same phase, decisions are taken with regard to the research subjects, the research fellows and assistants, the material to be utilized, and, finally, the style and the qualitative characteristics of the research target group.

In the second unit, the educational, theatro-pedagogical, and research methods employed for the materialization of the programme, are studied, estimated, and clarified.

The third unit involves negotiations over the outcomes of the whole intervention. Here, deliberation is payee on the insights regarding knowledge, skills, and abilities acquired by the intervention all target groups.

Taking account of the basic principles as well as European Quality Assurance in Vocational Education and Training ${ }^{28}$ we suggest the following methodological curs: 1. Planning, 2. Implementation, 3. Assessment, 4. Evaluation and 5. Review.

The suggested methodology for the materialization of our research recommendations is mainly based on the qualitative paradigm, while allowing the parallel implementation of quantitative methodological tools. Due to the idiosyncratic character of the research field, the research is suggested to be carried out (i) in scientifically flexible research plans, (ii) in scientifically preorganised research plans (iii) with quantitative data and statistical generalizations, and (iv) in research plans of mixed methodologies.

In our suggested pieces of social research, the approaches that bear a critical significance are those of action research and case study. These two methodological procedures could also be greatly benefited from the Grounded Theory ${ }^{29}$ paradigm. The insights that acquired from such a paradigm could provide the field with a plethora of techniques that promote creativity and novelty, such as brain storming, nominal group approaches, focus groups, the Delphi technique and its variations, etc.

Nevertheless, the very techniques of Drama-In-Education, could be considered as research approaches in themselves. These involve telephone conversations and interviews-in-role, hot seat, conscience alley, and various role-plays. In some pieces of research we suggest direct observation, interviews, questionnaires or documents. In cases where written speech is involved, we stress the necessity of a discourse analysis of the exchanged mails among participants, the content of their kept diaries, and life-journals. Life narratives could also serve as an excellent and flexible methodological tool, as they form a medium through which the complexities of the participants' feelings and subjectivities could be sufficiently revealed. Besides, videos, life charts and pictures could become invaluable data collection mediums into the bargain, whilst certain discussions among groups might be recorded and analysed by the participants themselves.

With the suggested research procedure we aspire not only at research conclusions concerning the matters at hand. We also aim at the participants' acquaintance with the methodological thinking and knowledge, which would greatly contribute to their own later research projects.

Finally, the meta-analysis of the pieces of research carried out from each research group could lead to conclusions, either general or more specific, and set new insights and dimensions to the already existing theories.

28 See: http://www.eqavet.eu/gns/home.aspx.

29 For the basic viewpoints of the Grounded Theory see the following basic books: Glaser \& Strauss 1967, Strauss1987, Strauss \& Corbin 1990. 


\subsection{Proposed Actions}

The activities of this programme mainly aim at the development of a cooperation among different social groups. The social groups where the research is mainly focused are elderly people, prisoners, museum-educators, teachers, students in faculties of Drama-in-Education of national Universities, and citizens of local communities.

Bellow are cited the programme's activities, which involve the following steps:

Planning, Realization, Quantitative Assessment, Evaluation and Review.

\section{ACTION 1: Drama in Education and Social Bodies}

- Laboratory with elderly people: Story development/ and small improvisatory dramas.

- Laboratory with convicts in Prisons: Theatrical Laboratory, development of story/social dramas and dialogues. This also involves an inquiry on personal identities through the techniques of educational drama.

- Drama in Education Laboratories in Museums: Here the dramatic activity will take place in archeological and cultural museums, public galleries and libraries.

- Research: the research group records and assesses the work in the museums, and sets the research action with questionnaires and semi-structured interviews.

- Conference on themes concerned with the relation of Educational Drama and Social Bodies.

- Publication of Conference Minutes.

- Work visits in European Universities for the dissemination of the research implications of the first phase of the programme.

- Creation of a web site for the Programme.

\section{ACTION 2: Narrative and Social Bodies}

\section{Phase A}

- Seminars on Narration and Storytelling undertaken by storytelling Specialists. This aims at providing the participants with storytelling skills, life skills.

o Narrating fairy tales: Lectures and workshops about the techniques concerned with the development of speech and narrative ability.

o Life narratives: Workshops on the techniques for the usage of oral narratives and their transformation in theatrical speech.

- A series of personal research pieces in these social places carried out by each member based on open structured interviews. Guidance of the research by the research group. Completion of the research pieces.

- Symposium on Narrative Procedures and Skills.

- Publication of a leaflet presenting the process of the "Narrative Group" and the implications of the research in public places.

- Publication of a book containing the collective study of the research having been carried out and with the sum-total of the results concerned with Narrative.

- Presentation at a Conference where the research group will present the implications/ results of the research on narrative. 
Phase B

- Narration of fairy tales in villages by senior women (grandmas). Development of workshops with senior citizens in various villages.

- Life narrations in villages by senior women (grandmas). Development of workshops with senior citizens in various villages.

- Life narrations in prisons by convicts and development of fairy tales. Development of workshops with convicts in rural prisons.

- $\quad$ Theatrical Presentation of fairytales and the stories of convicts in prisons by the members of the research group, where the audience will be prison convicts.

- Improvisational Dramas or theatrical performances of the fairy tales and life stories of the convicts by the members of the Narration Group in public places (parks, museums, theatres). This activity will take place with the full convent of the convicts.

- Presentation of the research results "Life Narratives of Prison Convicts" at a National Conference.

- Presentation of the research results "Life Narratives of Elderly Women" at a National Conference.

- Articles on narrative in locals and national press, presentations on TV and radio.

- Presentation of the Programme "Narratives of elderly and prison convicts" in schools and other educational bodies.

- Work visits in European Universities for the dissemination of Activity 2. This will also involve the organization of laboratories with students and representatives of social bodies.

\section{ACTION 3: Puppet Theatre}

- Development of a Research Centre for Puppet Theatre: In places granted by local authorities a research on Puppet Theatre is going to be carried out aiming at studying this performing art which forms a dynamic learning medium. In collaboration with schools, Universities and local cultural groups, the research programme will acquire a multidimensional character. The history of puppet theatre, will be studied together with its role in the education of young children. It will also take into consideration children with special needs (social learning, self-awareness, self-provision/ self -assistance), adolescents (creative access to maths, chemistry, physics, literature, history, biology etc.). Particular emphasis will be paid on the effects of puppet theatre on the elaboration and solution of personal and social problems of both children and adolescents. These involve drugs, alcoholism, HIV, school violence, divorce or death. Finally, the research group will focus on the concealing and therapeutic dimension of puppet theatre.

Secondary Activities:

- Creation of a sign and Posters

- National Conference on the cognitive, developmental, social as well as on the emotional and therapeutic dimensions of Puppet Theatre. 
- Organization of 3-day conferences dedicated to the art of Puppet Theatre with the collaboration of eminent Greek and foreign researchers.

- A 10-day summer camping dedicated to Puppet theatre where eminent puppet players and educators will be invited.

- A Puppet Theatre Festival is scheduled to be held at the end of the camping period where residents and specialists will show their work with puppets.

- Construction of a web site for the art of puppet theatre where the sum total of the research work will be exhibited, thus offering opportunities for interactive information and discussion. It will also accept comments, articles, studies by other research groups, as well as performances and workshops from Greece and abroad.

- Formation of a working group of citizens and students "Puppetcosmos". The adult participants are going to be trained in the making and animating of puppets so that the puppet would become an effective means in their profession. The group members will meet every 20 days for three hours each day and for a total period of three years with new registrations every single year.

- Applications: Every participant in the Puppet Group will apply this art in his or her working place. Besides, and under the guidance of the research group and the guest specialists he or she will move on to a personal assessment with regard to the role of Puppet Theatre as a means for the attainment the aims set in his or her professional post.

- Publication of a Book, where the work of the participants of the working group will be summarized.

- A course of Action Research with the mentioned group where the principal researcher will reflectively collect and organize data from the whole action of the group.

- Publication of a Book where the work of the participants of the working group will be summarized.

- Exhibition of the construction material and of the constructed puppets from the participants in public places.

- Puppet Shows in public places and TV channels by the participants.

- Presentation of the whole body of the research on Puppet Theatre by the Research Group at a National Conference.

- Presentation of the whole body of the research on Puppet Theatre by the Research Group at a National Conference.This will also involve suggestions for further research on the same topic.

- Organization of a library with the Puppet Theatre plays of the members of the research groups Organization of a library with Puppet Theatre plays from all over the world.

- Work visits to European Universities for the dissemination of research implications of the Activity 3 of the programme. 


\section{ACTION 4: School for Immigrants}

This activity refers to schools where the Greek language is taught to immigrant or repatriated pupils with the techniques of Drama in Education. Through the fostering of their creativity immigrant students are encouraged to express themselves through images, plastic arts, puppets, songs, dance, and improvisational dramas.

The work will also be enriched with other means of expression such as publication of newspaper, keeping a diary in role, writing in role, writing improvisational dialogues, writing theatre plays, performing with puppets, and shadow theatre.

Classes take place every Sunday afternoon for three hours each time and for a total period of one year. In a second phase (and in relation to the interest of the immigrant students) a second level of learning is scheduled to be organized. It is aimed that the school will end up involving three levels of language teaching.

The teaching staff will be composed by pensioner and unemployed teachers and by students who have attended a fast-paced intensive course on Language teaching.

The school will be based on the premises of the University or at another public place.

Secondary Activities:

- Fast-paced training of the staff on the teaching of the a language through art by specialists (University teachers and artists).

- Development of Educational material for the teaching of a language through art.

- An Action research Programme for the collection of reflective data, which will last one year.

- Presentation of the results of the action Research in a National Conference. This will also involve suggestions for future research.

- Construction of a video-library. This will involve videos containing simple dialogues, narratives, puppet shows, advertisements and other material facilitating the learning of Greek language in a playful and non-constrained way.

- Presentation of videos made by immigrants. With the help of specialized photographers, immigrants make their own videos which are presented in a special occasion.

- Construction of a library with books for children and manuscripts containing simple texts.

- Expansion of the language school in prisons. People who have been trained to teach in the School of Immigrants also work employ similar techniques in language teaching to the convicts of prisons.

- School of PhD students in Drama in Education. Every summer PhD students whose subject is related to the Arts, Drama and Creative writing are invited to stay for three days in the University to present their work and interact with the aim of offering new insights regarding the understanding coping with issues concerning the involvement of the arts in education. 


\section{ACTION 5: Lets Go Theatre}

- School of theatrical Performances. Students and adult citizens of local areas are encouraged watch selected professional theatrical performances. The end of each performance is followed by a discussion with the contributors of each play.

- Interviewing Theatre Directors. Every student interviews an eminent theatre director. The transcript of the interview is uploaded on the website. All interviews will have the pattern of a semi-structured research interview.

- Invitation of famous directors - Lectures and workshops.

o Conversation -Communication with imminent theatre directors. A number of well known directors are called by the leaders of the programme each year. Students and local people have the opportunity to gather together, to know each director and converse with each one of them so as to broaden their understanding of Theatre.

o Workshops with directors invited from abroad: each workshop will last a week and will be attended by a different work group each time.

\section{ACTION 6: School of Tourism}

Through the techniques of Educational Drama, and along with the process of Lifelong learning, Theatrical workshops and Tourism are suggested to be organised. Professional tourist agents are initiated in the techniques of Educational Drama. The desirable aim of such an activity is the development to the participants of a number of professional abilities such as communicative skills, problem solution skills, management, anticipation, planning and reviewing.

- Recordings and "case study" of the tourism school by the research team.

- International Conference on the Role Drama in Education and Lifelong Learning.

\section{Concluding Note}

In the context of the present work we attempted a brief presentation of the educational potentials of play and drama in education, accompanied with suggestions for finished actions in diverse social, cultural and educational milieus. To accomplish such a venture we borrowed from research implications from of Theatre-Pedagogy Social Sciences. Besides, we considered the basic programmatic views of European and international bodies, that deal with issues concerning culture, art, innovation and lifelong learning.

It has to also be noted here, that we did not aspire in a complete and thorough consideration of what might be termed "Theatre-Pedagogy"; a notion that is becoming constantly more welcomed in academic and educational communities. In order to dispense for such paucity, we involved a rather broad bibliographical section with a good number of references aiming to explicate further the above mentioned notion, and to offer sufficient justifications for its place in education and society at large. 
The establishment of dramas' legitimacy in the above mentioned contexts, forms the major aim of the present work. And in order $t$ an aim, we involved a good number of potential projects that focus on the flow of meaning among diverse cultural, social and educational territories. Besides, and in view of the recent expansion of the phenomenon of immigration we placed particular emphasis on the noon of inter-culturalism as well as the role that language and speech play in the formation of local cultures.

Apart from all the above, we underlined the art of puppet theatre, whose exceptional medium, renders it capable to link together diverse cultures and age groups, whilst in our suggested activities we involved the elderly, counting on to their accumulated experience and knowledge.

Of course, the possible applications of drama-in-education appear to be inexhaustible. As an example, we mentioned Mental Health Centres, Special-education Centres, abandoned buildings, storehouses, factories, earthquake victims, or victims of other physical disasters, minorities.

The field is significantly fruitful and productive, whereas, through its constant expansion and growth, it offers novel opportunities for inter-cultural, and interdisciplinary approaches, competent with theater's very nature as a place of creative encounters among diverse communities.

\section{References}

Abbs, P. (1979). Reclamations: Essays on Culture, Mass-Culture and the Curriculum. London: Heinemann

Abbs, P. (2003). Against the Flow. London: Routledge

Adigüzel, H. Ö. (2008). The Recent History of Creative Drama in Education in Turkey, in: Yaratici Drama Dergisi, Creative Drama Journal Vol. 1, issue 5, pp. 29-49

Bell, C. (1914). Art. New York: Frederick Stoke Publishers

Best, D. (2012). The Rationality of Feeling: Learning From the Arts. London: Routledge

Boal, A. (1993). Theatre of the Oppressed. New York: Theatre Communications Group

Boal, A. (1996). Politics Education and Change, in: O' Tool, J. \& Daneman, K. (eds) (1996). Drama, Culture and Empowerment. The IDEA Dialogues. Brisbane IDEA Publications

Bolton, G. (1982). Drama as Learning, as Art and as Aesthetic Experience, in: Ross, M. (ed). The Development of the Aesthetic Experience. London: Pergamon

Bruner, J. (1979). On Knowing: Essays for the Left Hand. Belknap Press of Harvard University Press

Bruner, J. (1990). Acts of Meaning: Four Lectures on Mind and Culture (Jerusalem-Harvard Lectures). Cambridge: Harvard University Press

Bruner, J. (1996). The Culture of Education. Cambridge: Harvard University Press

Cassirer, E. (20102). Versuch über den Menschen: Einführung in eine Philosophie der Kultur. Hamburg: Felix Meiner Verlag

Cattanach, A. (19962). Drama for People with Special Needs. London: A \& C Black 
Coleridge, S. T. (1907). 'Biographia Literaria" vol. II. Oxford: Clarendon Press

Domkowsky, R. (2011). Theaterspielen - und seine Wirkung. (Doktorarbeit). Berlin: Universität der

Künste Berlin (http://opus4.kobv.de/opus4-udk/frontdoor/index/index/docId/25)

Dörger, D. \& Nickel, H.-W. (2005). Spiel- und Theaterpädagogik studieren. Berlin u.a.: Schibri

Doyle, C. (1993). Raising Curtains in Education: Drama as a Site for Critical Pedagogy. London: Bergin \& Garvey

Fines, J. and Verner, R. (1974), The Drama of History: An Experiment in Co-Operative Teaching. London: New University Education

Fischer-Lichte, E. (1999). Geschichte des Dramas I. Von der Antike bis zur deutschen Klassik. Stuttgart: UTB

Fischer-Lichte, E. (2008). The Transformative Power of Performance: A New Aesthetics. (Translator: S. I. Jain). London: Routledge

Fuchs, M. (1999). Mensch und Kultur. Anthropologische Grundlagen von Kulturarbeit und Kulturpolitik. Wiesbaden: Westdeutscher Verlag

Fuchs, M. (2011). Die Macht der Symbole. Ein Versuch über Kultur, Medien und Subjektivität. München: Herbert Utz

Glaser, B. G. \& Strauss, A. L. (1967). The Discovery of Grounded Theory: Strategies for Qualitative Research. New York: Aldine

Goleman, D. (2004). Emotional Intelligence - why it Can Matter More Than IQ \& Working with Emotional Intelligence. New Jersey: Penguin Group

Gombrich, E. H. (1960). Art and Illusion. London: Phaidon

Grammatas, Th. (2012). Introduction to History and Theory of Theatre. Athens: Exandas (in Greek)

Hentschel, U. (2008). The So-Called Real. Playing With Reality in Theatre And Theatre Pedagogy Speech given in Warschaw on October 4th, 2008, in: http://www.udk-berlin.de/sites/ theaterpaedagogik/content/e348/e111003/e111004/infoboxContent111008/Theso-CalledReal ger.pdf?preview=preview

Hentschel, U. (2010). Theaterspielen als ästhetische Bildung. Über einen Beitrag produktiven künstlerischen Gestaltens zur Selbstbildung. Berlin u.a.: Schibri

Koch, G. (1998). Lernen mit Bert Brecht. Bertolt Brechts politisch-kulturelle Pädagogik. Frankfurt/M.: Brandes \& Apsel

Koch, G. (2012). Theater: autonom und sozial. In: Szenario, VI, Issue 1 (2012), p. 10-26 (see: http:// publish.ucc.ie/scenario/2012/01/koch/02/de)

Kondoyianni, Alkistis (2008). Black Cow - White Cow: Drama in Education and Interculturalism. Athens: Topos (in Greek)

Langer, S. (1977). Feeling and Form. New Jersey: Prentice Hall

Lehmann, H.-Th. (2006). Postdramatic Theatre. (Translator: K. Jürs-Munby). London: Routledge 
Lenakakis, A. (2004). Paedagogus Ludens. Erweiterte Handlungskompetenz von Lehrer(inne)n durch Spiel- und Theaterpädagogik. Berlin u.a.: Schibri

Lenakakis, A. (2012). Theatre/Drama-Pedagogy and intercultural learning, in: Androulakis, G./ Mitakidou, S./Tsokalidou, R. (eds). (2012). Proeedings Crossroad of Languages and Cultures learning beyond Classroom. Thessaloniki: Polydromo, Faculty of Education, Aristotle-University of Thessaloniki, pp. 114-128 (in Greek)

Levi-Strauss, C. (1963). Structural Anthropology. New York: Basic Books

Marcuse, H. (1978). The Aesthetic Dimension. New York: Beacon Press

O’ Tool, J. (1992). The process of Drama. London: Routledge

O’ Tool, J. \& Daneman K. (eds) (1996). Drama, Culture and Empowerment. The IDEA Dialogues. Brisbane IDEA Publications

Olson, D. R. \& Torrance, N. (eds) (1999). The Handbook of Education and Human Development: New Models of Learning, Teaching and Schooling. Oxford: Wiley-Blackwell

Pammenter, D. \& Mavrocordatos, A. (2003). Cultural Action for the Socials Transformation, in: Govas, N. (ed). Drama in Education. Bridging the Gaps. Athens: Metechmio (in Greek)

Pinkert, U. (2005). Transformationen des Alltags. Transformationen der Berliner Lehrstückpraxis und Live Art bei Forced Entertainment. Modelle, Konzepte und Verfahren kultureller Bildung. Berlin u.a.: Schibri

Reid, L. A. (1986). Ways of Understanding and Education. London: Heinemann

Ross, M. (1978). The Creative Arts. London: Heinemann

Ross, M. (1984). The Aesthetic Impulse. London: Pergamon

Schechner, R. (1988). Performance Theory. London: Routledge

Schiller, F. (2004). On the Aesthetic Education of Man. (Translator: R. Snell). New York: Dover Publications

Slade, P. (1953). Child Drama . London: London University Press

Somers, J. (2006). Drama as Social Intervention, in: http://hdl.handle.net/10072/12646

Strauss, A. L. \& Corbin, J. (1990). Basics of Qualitative Research. Grounded Theory. Procedures and Techniques. Thousand Oaks, CA: Sage

Strauss, A. L. (1987). Qualitative analysis for social scientists. Cambridge: Cambridge University Press

Taylor, P. (2000). The Drama Classroom. London: Routledge-Falmer

Turner, V. (1974). Dramas, Fields and Metaphors. Symbolic Action in Human Society. New York: Cornel University Press

Turner, V. (1978). The Ritual Process. Harmonsworth: Penguin

UNESCO (2006). The Road Map for Arts Education, in: http:/www.unesco.org/new/en/culture/themes/ creativity/arts-education

UNESCO (2010). The Seoul Agenda: Goals for the Development of Arts Education, in: http://www. 
unesco.org/new/en/culture/themes/creativity/arts-education

Vygotsky, L. S. (197814). Mind in Society: The Development of Higher Psychological Processes. Cambridge: Harvard University Press

Vygotsky, L. S. (2012). Thought and Language. Cambridge: The MIT Press (revised and expanded edition)

Winnicott, D. (1992). Through Paediatrics to Psycho-Analysis: Collected Papers. New York: BrunnerRoutledge

Winnicott, D. (20052). Playing and Reality. London: Routledge

Witkin, R. (1974). The Intelligence of Feeling. London: Heinemann

Witkin, R. (1989). Expressivist Theories of Art and Ideologies of Arts Education, in: Ross, M. (ed). The Claims of Feeling. London: Falmer 


\section{Eğitimde Yaratıcı Dramaya Dayalı Külttürlerarası ve Yaşam Boyu Öğrenme: Çok Boyutlu Araştırma Projelerine İlişkin Yönelimler ${ }^{1}$}

\author{
Alkistis Kondoyianni \\ Peloponnese \\ Üniversitesi
}

\author{
Antonis Lenakakis \\ Thessaloniki Aristo \\ Üniversitesi
}

\author{
Nikos Tsiotsos \\ İlköğretim Okulu
}

Eğitimde yaratıcı drama eğitim-öğretim sürecinin her evresinde ve yaşam boyu öğrenme bağlamında oldukça etkili olarak kullanılmaktadır. Her düzeyde formal eğitimi desteklemesi ve öğrencilerin başarısını olumlu yönde etkilemesi yanında entelektüel düşünme becerisini geliştirmesi, önyargıları azaltması ve genel olarak çocuk ve gençlerin estetik eğitimine katkıda bulunması eğitimde dramanın yararları arasındadır. Yetişkin eğitiminin her alanında da eğitimde yaratıcı drama etkili biçimde kullanılmaktadır. Bu nedenle eğitimde yaratıcı drama, yalnızca üniversitede drama bölümlerinde değil, sosyoloji, tıp, yabancı diller ve teknoloji gibi farklı disiplinlerde de kullanılmaya başlanmıştır.

\section{Eğitimde Yaratıcı Drama ve Tiyatro Pedagojisi}

Çalışmamız bir yandan farklı bilimsel, kültürel ve sosyal gruplarla iş birliği ve planlama çalışmalarını ele alırken diğer yandan da yaratıcı etkinlikler ve sanatsal anlatımların farklı biçimlerini bir araya getirmeyi hedeflemektedir. Böyle bir birliktelikte, insanın yaratıcıllğı ve insanın keşfediciliğini ortaya çıkarmaya yarayan ortak form ve uygulamaları içeren sanat ve drama, çalışmamızın odağını oluşturmaktadır. Özellikle tiyatro bağlamında düşündüğümüzde farklı ortam ve mekânlarda farklı gruplar, ülkeler ya da toplumlar bir araya gelmekte ve tiyatral çalışmaları kendi geleneklerine göre eş zamanlı ya da farklı zamanlarda sunabilmektedirler. Çünkü tiyatro ya da drama çalışmaları bireylerin fiziksel ya da kültürel farklılıklarını ön plana çıkarmadan insanlar arasında ortak paylaşımların oluşmasına olanak verir; çünkü drama çalışmaları evrensel boyutta bireylerin, özlemleri, tutkuları, mutluluk ya da hayal kırıklıkları ile hayal ve gerçeklerini bir araya getirir, bir diğer söyleyişle gündelik yaşamı gerçek ve kurgusal boyutta ele alır. Drama ve tiyatro çağdaş yaşamda düşünce ve davranış kalıplarına ilişkin iletişim kanallarını da çoğaltır. Bireylerin kendi kimlik, ideal ya da sosyal değerlerini oluşturmalarına yardımcı olacak temel rol modellerini prova etmeye yardım eder.

Drama ve sanat, genel olarak dünyayı algılama ve kavramaya yönelik etkili araçlar sağlar, yalnızca insanların eylemlerinin doğal ve sosyal yasalarını arama yoluyla değil aynı zamanda doğal ve soysal fenomenlere bütünsel olarak ulaşmaya olanak veren imajları da yaratmayı sağlar. Tiyatral süreçler aracılığıyla insanlar her bireyin yaşadığı dar çevreden çok daha geniş ve zengin bir bütün olarak dünyayı anlayabilirler.

Drama çalışmaları yetişkin ve çocukların eylem ve performanslarında hem oyuncu hem de

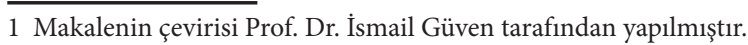


özne ve nesne olmalarına olanak verir. Yaşamın kuralları, oyunun kurallarıyla iç içe geçer, oyunda sembolik etkinlikler dişsal gerçeklerin keşfedilmesine uygun ortam sağlar.

\section{Avrupa ve Uluslararası Kuruluşların Program Belgeleri}

Sunulan araştırma önerileri, bizden özellikle Avrupa Birliği ve diğer uluslararası kuruluşların sunduğu metinler üzerine öncelikle odaklanmamızı zorunlu kıldı. Çalışmamızın temel amacı var olan metinlerde yer alan, felsefi anlayış, öncelikler ve temel ilkeleri ortaya çıkarabilmekti. Bu anlayışlara ulaşabilmek için üç temel alanla ilgilendik: Sanatın eğitim ve bilgi değişimine yönelik konularda ulusal ve uluslararası işbirliğine katkısı, daha nitelikli bir eğitim, yaşam boyu eğitim ve yetişkin eğitimi için yaratıcılık, bilgi paylaşımı ve eğitimsel araştırmaların geliştirilmesi gibi konular.

Bu nedenle,

- "Europe 2020", Avrupa Kalite Yönetimi ve Mükemmeliyet Modeli Kuruluşu Belgesi (2010), Avrupa Konseyi Eğitim ve Öğretim Raporları sonuçları, Avrupa’nın farklı eğitim ve kültürel alanda çalışma programları ve işbirliği belgeleri incelenmiştir. UNESCO 2006 Sanat Eğitim Yol Haritası, 2010 Seul Gündemi, Sanat Eğitiminin Geliştirilmesine Yönelik Hedefler: belgeleri ele alınmıştır. Ayrıca sanat, eğitimde drama ve tiyatro eğitiminin uluslararası boyutunda yapılan çalışmaların sonuçları paylaşılmıştır.

\section{3. Öngörülen Araştırma amaçları}

Öngörülen araştırma ve çalışmalarla hem bireyler hem de drama gruplarına belli hedefler oluşturmak amaçlanmıştır. Avrupa ve uluslararası düzeyde ve ulusal düzeyde grupların "Eğitimde Drama Çalışmaları"na katılmaları hedeflenmiştir:

Grup ya da hedef gruplar için, nitel ve nicel açıdan önemli olan yaşam boyu öğrenme olanakları oluşturma, kişisel bütünleşme ve sosyal uyumu geliştirmeye yönelik eğitim kültürünün oluşturulması

- Sanatsal ifade ve yaratıcılığın teşvik edilmesi

- Bilgi ve düşüncelerin sosyal olarak oluşturulmasına yönelik araştırma projelerinin geliştirilmesi

- Etkileşimli iletişim ortamlarının güçlendirilmesi

- Grupların çok boyutlu gelişiminin sağlanması

- Sözel ve sözel olmayan kişilerarası ve gruplar arası iletişim becerilerinin geliştirilmesi

- Uzlaşı, çatışma çözme becerilerinin geliştirilmesi

- Empati becerilerinin zenginleştirilmesi

- Ekiple çalışma ve işbirliğinin geliştirilmesi

- Hakkını savunma vb. becerilerin oluşturulması

- Karar alma ve sorun çözme, eleştirel düşünme becerilerinin geliştirilmesi

- Kayg1 ve korkulardan uzaklaşma ve kaygı yönetimi

- Öğrenmede duygusal boyutun katılımının güçlendirilmesi 
- Gruplardaki her bireyin yetenek ve kişisel gelişimlerinin sağlanması

$>$ Yerel ve Avrupa düzeyinde ise

- Küçük ölçekli ve büyük ölçekli çalışmalar aracılığıyla yer topluluklar ve üyeler arasındaki yaratıcı etkinliklerin geliştirilmesi

- Yerel düzeyde alt kültürlere yönelik çalışmalar ve yaşam boyu öğrenmenin vurgulanmas1, çok sesliliğin geliştirilmesi

- Yerel toplumlar içinde kültürel kuruluşların geliştirilme çabalarının destelenmesi

- Kültürel ve diğer sosyal örgütler arasında yatay ve dikey işbirliğinin geliştirilmesi

- Kültür turizmi adı verilen projelerin desteklenmesi

- Kültürel ve doğal mirasın korunması gerekliğine ilişkin çevre eğitimi programlarının desteklenmesi

- Üniversite ve yerel kuruluşlar arasında yaratıcı ve verimli işbirliği çalışmaları

- Avrupa düzeyinde ulusal üniversitelerle, Avrupa üniversiteleri ve diğer eğitim kurumları arasında işbirliğini geliştirip, araştırma sonuçlarını paylaşma

- Katılımcı vatandaşlık eğitim programlarını geliştirme

- Araştırmacı, sanatçı ve vatandaşların hareketliliğini geliştirme

\section{4. Önerilen Araştırma Çalışmalar}

\subsection{Araştırma Amaçları}

Burada sunulan araştırma çalışmaları eğitimde yaratıcı dramanın sosyal ve kültürel alanda etkisi ve rolüyle ilgi konulardır. Müzeler, yaşlı bakım merkezleri, hapishaneler, yerel kültürel birimler, zihin engellilere yönelik kurumlar, oyun merkezleri, sosyal oluşumlar ya da galerilerin tümünde eğitimde drama çalışmaların tümü araştırma konusu yapılabilir.

\section{2 Önerilen Yaklaşımlar}

Araştırma yöntemleri olarak 1. Temel Araştırmalar 2. Deneysel Araştırmalar yapılabilir.

Mesleki Eğitimde Avrupa Kalite Öngörüsü ilkeleri göz önünde bulundurularak aşağıdaki yöntemsel başlıkları önerebiliriz: 1. Planlama, 2. Uygulama, 3. Ölçme, 4. Değerlendirme, 5. Gözden geçirme.

Araştırma alanının kendine özgü niteliği nedeniyle, (i) bilimsel açıdan esnek planları olan (ii) bilişsel olarak ön organize edici planları olan, (iii) niteliksel ve istatistiksel genellemelere yer veren (iv) karma yöntemleri içeren araştırma önerileri verilebilir. Ayrıca taban teorisinden de yararlanılabilir.

Bununla birlikte yöntemleri etkili olarak uygulayabilmek için eğitimde yaratıcı dramanın farklı teknikleri de işe koşulabilir. Katılımcıların yöntemsel düşünme bilgiyle karşılaşmalarını ve bunlar ışığında daha sonra kendi araştırma projelerini geliştirmelerini hedefliyoruz.

En son çalışma ise farklı araştırma çalışmalarında ortaya çıanları bir araya getirip yeni bir sentezle sunan meta analiz çalışmalarının yapılmasını öngörmektedir. 


\section{2 Öngörülen etkinlikler}

$\mathrm{Bu}$ programın temel etkinlikleri; yaşl1lar, mahkumlar, müze eğitimcileri, eğitimde drama konusunda öğrenim gören öğrenciler, üniversiteler ve yerel otoriteler gibi farklı gruplar arasında işbirliğini hedeflemektedir.

Sözü edilen etkinlikler şu basamakları içermektedir:

Planlama, uygulama, niteliksel ölçme ve değerlendirme ve gözden geçirme.

\section{EYLEM 1: Eğitimde Drama Sosyal Yapılar}

- Yaşlilarla laboratuvar çalışmalar

- Hapishanelerde yapılan çalışmalar

- Müzede drama çalışmaları

- Müzelerdeki çalışmaları kaydeden ya da değerlendiren araştırmalar

- Eğitimde drama ve sosyal kurumlar arasındaki ilişkileri alan konferanslar

- Konferans tutanaklarının basımı

- Avrupa müzelerinin ziyaret edilmesi

- Programa yönelik web sitesinin kurulması

\section{EYLEM 2: Anlatı ve Sosyal kurumlar}

\section{A Evresi:}

- Öykü anlatımı ve anlatı konusunda uzman olanlar tarafından seminerler yapılması

o Masalların anlatımı: seminer, atölye çalışmaları

o Canlı anlatılar: sözlü anlatıların tiyatral dile dönüştürüldüğü tekniklere yönelik atölye çalışmaları

- Yapısal görüşmelere dayalı olarak gerçekleştirilmiş olan sosyal mekânlardaki kişisel araştırma çalışmalarının derlenmesi

- Anlatı süreç ve becerilerine yönelik sempozyumlar

- “anlatı grupları"ndaki süreçleri ortaya koyan el kitabı vb. Dokumanın yayımlanması

- Anlatıyla ilgili araştırmaları içiren bir eserin yayımlanması

- Anlatıyla ilgili araştırma sonuçlarının konferansta sunulması

B Evresi:

- Köylerde Yaşlıların anlattığ masalların toplanması

- Köylerde yapılan canlı anlatılar

- Cezaevlerinde mahkûmların yaptıkları canlı anlatılar

- Cezaevlerinde kalanların öykü ve masalları tiyatral canlandırması

- Mahkûmların masal ya da hayat hikâyelerine yönelik tiyatral sunu ya da doğaçlamalar

- Mahkûmların canlı anlatılarına yönelik araştırma bulgularının ulusal konferanslarda sunumu 
- Yaşlıların canlı anlatılarına yönelik araştırma bulgularının ulusal konferanslarda sunumu

- Yerel ve ulusal basında anlatılara yönelik makalelerin yayımlanması ve sunular yapılması

- Yaşlı ve mahkûmlardan derlenen anlatıların okul ya da diğer kurumlarda sunulması

- Anlatıların sonuçlarının Avrupa Üniversitelerinde sunulması

\section{EYLEM 3: Kukla Tiyatrosu.}

- Kukla Tiyatrosuna Yönelik Araştırma Merkezinin Gelişstirilmesi. Yerel otoritelerce desteklenecek araştırma projelerinin sağlanması, okullar, üniversiteler ve diğer kültür gruplarının bir araya gelerek kukla tiyatrosu konusunda çalışmalar yapmasının sağlanması. Kukla tiyatrosunun çocukların eğitiminde kullanılmasının yanı sıra, ergen ve gençlerin sorunlarına yönelen çalışmalar yapılması.

İkinci Etkinlikler:

- Sembol ve posterlerin oluşturma

- Kukla tiyatrosunun terapik, duyuşsal boyutlarına yönelik ulusal konferanslar yapma

- Kukla tiyatrosu konusuna ayrılmış, yerli ve yabancı uzmanların katıldığı kısa süreli konferanslar yapma

- Kukla tiyatro festivali düzenleme

- Kukla tiyatrosu etkinliklerinin öğretimine dayalı yaz kampları gerçekleştirme

- Kukla tiyatrosu ile ilgi çalışmaları paylaşmayı sağlayacak web sitesi kurma

- Kukla tiyatrosu geleneğinin oluşturulmasına yönelik öğrenci ve diğer kişilerin katılacağı çalışma grupları oluşturma

- Uygulamalı çalışmalar: Kukla tiyatrosuna katılmak isteyenlere katılma olanağı ve deneyimler elde etme uygulama olanăğ verme.

- Uygulamalı çalışmalara katılanların çalışmalarını belgeleyen kitap basımı

- Eylem planı çalışmalarını geliştirme

- Kamusal alanda katılımcıların yer aldığı kukla yapım teknikleri malzemelerinin sunulduğu sergiler

- Medya ve basinda kukla gösterileri yapma

- Kukla tiyatrosu araştırma ve çalışma gruplarının etkinliklerini tanıtan ulusal kongreler yapma

- Kukla Tiyatrosuna yönelik kütüphane oluşturma

- Üniversitelere ziyaretler ve çalışmaların paylaşılması

\section{EYLEM 4: Göçmenlere yönelik okullar}

Eğitimde drama teknikleriyle göçmenlerin farklı dil becerilerini geliştirebileceği etkinlikler gerçekleştirme. Şarkı, dans, plastik sanatlar ve doğaçlamalar yoluyla göçmen çocukların kendilerini ifade etme becerileri kazandırma çalışmaları yoluyla yaratıcılık geliştirilebilir. Çalışmalar okul saatleri dışında yapılabilir. Burada çalışacak kişiler, dil öğretmenleri emekli 
öğretmenler ya da çalışan öğretmenler olabilir.

İkincil Etkinlikler

- Yoğun kurslar yoluyla eğiticilerin eğitimi

- Sanat yoluyla dil öğretimine yönelik eğitim verilmesi

- Sanat yoluyla dil öğretimine yönelik eğitimsel materyallerin geliştirilmesi

- Eylem planlarinin geliştirilmesi

- Araştırma ve uygulama sonuçlarının ulusal kongrelerde sunulması

- Video kütüphanesinin oluşturulması

- Göçmenlerin yaptıkları videoların sunulması

- Göçmen çocukların yararlanabileceği anlaşılabilir ve teknik olmayan makale ve kitapların bulunduğ u bir kütüphanenin oluşturulması

- Hapishanelerde dil öğretiminin gerçekleştirilmesi

- Eğitimde yaratıcı dramaya yönelik Doktora eğitimine geçilmesi

\section{EYLEM 5: Haydi Tiyatroya Gidelim}

- Tiyatro gösterilerine yönelik okulların hazırlanması

- Tiyatro yönetmenleriyle röportaj vb. çalışmalar yapılması

- Tanınmış yönetmenlerin okullara davet edilmesi, konferans ve atölye çalışmaları yapilmas1

\section{EYLEM 6: Turizm Okulu}

Yaşam boyu öğrenme ve eğitimde yaratıcı drama teknikleri yoluyla, tiyatral atölyeler ve turizmi destekleyici çalışmalar yapılabilir. Tur rehberlik ajansları ve rehberlerine yönelik eğitimde dramanın kullanıldığı eğitim programları oluşturulabilir.

- Örnek olay çalışmaları yapılabilir

- Yaşam boyu öğrenme ve eğitimde yaratıcı dramanın rolüne ilişkin konferanslar gerçekleştirme

\section{Sonuç}

$\mathrm{Bu}$ çalışma eğitimde yaratıcı drama ve oyunun eğitimsel yönüne ile farklı sosyal, kültürel ve eğitimsel konularda yapılmış çalışmalarda ortaya çıkmış sonuç ve önerilere kısa bir bakış açısı sunmaktadır. Yapılan çalışmalarda sanat, kültür ve yaşam boyu öğrenme bağlamında eğitimde drama çalışmalarına dayalı farklı uygulamalarda oldukça önemli sonuçlara ulaşılmıştır. "Tiyatro-eğitimi" kavramının akademik çevreler ve eğitimciler tarafından da gitgide daha fazla benimsendiği ortaya çıkmıştır. Eğitimde yaratıcı drama hem bir sanat formu hem disiplin hem de eğitim aracı olarak farklı biçimlerde kullanılmışıır ve Avrupa düzeyinde kullanılmaya devam etmektedir. 
